\title{
Long or short silicic magma residence time beneath Hekla volcano, Iceland?
}

\author{
Olgeir Sigmarsson ${ }^{1,2}$, Ingibjörg A. Bergpórsdóttir ${ }^{2}$, Jean-Luc Devidal ${ }^{1}$,
} Gudrún Larsen ${ }^{2}$ and Abdelmouhcine Gannoun ${ }^{1}$

\author{
${ }^{1}$ Laboratoire Magmas et Volcans, Université Clermont Auvergne - CNRS, Campus Universitaire des \\ Cézeaux, 6 avenue Blaise Pascal, 63178 Aubière, France \\ ${ }^{2}$ NordVulk, Institute of Earth Sciences, University of Iceland, 101 Reykjavik, Iceland \\ (e-mail: olgeir@hi.is; ORCID\#0000-0002-0639-6187)
}

\begin{abstract}
Timescales of magma transfer and differentiation processes can be estimated when the magma differentiation mechanism is known. When conventional major- and trace-element analyses fail to distinguish between various processes of magma differentiation, isotope compositions can be useful. Lower Th isotope ratios in silicic relative to basaltic magmas at a given volcano, could either result from magma storage over a period of several tens of thousands of years of if the differentiation process was fractional crystallisation alone, or from crustal anatexis on a much shorter timescale. Recently mapped bimodal tephra layers from Mt. Hekla, Iceland, confirm lower $\left({ }^{230} \mathrm{Th} /{ }^{232} \mathrm{Th}\right)$ and higher $\mathrm{Th} / \mathrm{U}$ in silicic versus mafic magmas. Higher $\mathrm{Th} / \mathrm{U}$ has been taken to indicate either apatite fractionation or partial crustal melting. In-situ trace element analysis of apatite and the enveloping glass in basaltic andesite, dacite and rhyolite was undertaken to examine its capacity to fractionate trace elements and their ratios. Both Th and $U$ are compatible in apatite with a partition coefficient ratio $\mathrm{D}^{\mathrm{U}} / \mathrm{D}^{\mathrm{Th}}$ of 1. Hence, apatite crystallization and separation from the melt has a negligible effect on $\mathrm{Th} / \mathrm{U}$ in Hekla magmas. Partial melting of hydrothermally altered crust remains the preferred mechanism for producing silicic melt beneath Hekla. Ten to twenty percent partial melting of metabasaltic crust with 0.4-1.2 wt $\% \mathrm{H}_{2} \mathrm{O}$ produce dacite magma with 4-6\% water. Absence of low $\delta^{18} \mathrm{O}$ values in Hekla magmas compared to silicic magmas of the rift-zones suggests mild hydration of the hydrothermally altered crust. Silicic magma formation, storage, differentiation and eruption at Hekla occurred over a timescale of less than a few centuries. Decreasing production of rhyolite and dacite during the Holocene lifetime of Hekla suggests changes in the crustal magma source and readjustment of the magma system with time.
\end{abstract}

\section{Keywords Magma differentiation timescales, tephra, apatite, partition coefficients, $T h / U$}




\section{Introduction}

An important research goal for better understanding volcanic behaviour is the evaluation of how fast magma differentiates at depth and how quickly it ascents through the crust. The timescales of magma transfer after a mixing event of two magma types, or thermal perturbations, is often recorded in mineral zonation (e.g. Costa et al. 2020 and references therein) whereas zircon-ages suggest several order of magnitude longer timescales (e.g. Cooper \& Reed 2008). Information on the timescale of magma differentiation derived from U-series disequilibria on whole-rocks depends on a good understanding of the magma fractionation process(es) and how different elements of the U-series respond (e.g. Condomines et al. 2003). The occurrence of low Th isotope ratio in more silicic magmas from several active volcanoes such as Teide (Tenerife, Canary Islands), Snæfellsjökull and Hekla volcanoes (Iceland; Fig. 1a) have been interpreted as reflecting several tens to hundreds of thousands of years of closed- or open-system fractional crystallisation of mafic magma before the eruptions (Hawkesworth et al. 2000; Kokfelt et al. 2009; Chekol et al. 2011). Similarly, ${ }^{238} \mathrm{U}^{230} \mathrm{Th}$ radiosactive equilibrium in continental rhyolites from North America were explained by inferring a crustal residence time of $>10^{5}$ years (Reagan et al. 2003). These long timescales have also been suggested from zircon compositions in rhyolite at the Yellowstone caldera (Stelten et al. 2015) and in a silicic tephra from Hekla (Carley et al. 2011). In marked contrast, the complete magma suite from basalt to rhyolite of Hekla volcano would have been produced over a period that was one or two orders of magnitude shorter (hundreds to thousands of years) if the silicic magma result from crustal anatexis (Sigmarsson et al. 1992). Therefore, estimations of time elapsed from magma generation to eruption depend on a detailed knowledge of the magma generation, and thus of the differentiation mechanisms.

Magma differentiation processes generating silicic melt have been debated for a long time. Fractional crystallisation, assimilation fractional crystallisation (AFC), melting of crustal silicic segregations or fluid-absent melting of hydrated metabasalts (amphibolites) have been proposed to explain the abundance of silicic magmas in Iceland (see review by Jónasson 2007 and references therein). All of these processes have been shown to be capable of producing silicic melts with the appropriate major-element composition, though their efficiency most likely depends on the crustal thermal regime (Martin and Sigmarsson, 2007; Schattel et al. 2014). Silicic magma at Askja, Krafla and Torfajökull volcanoes, all of which have developed powerful geothermal systems, have different isotope ratios to contemporaneously erupted basalts, and are thus ascribed to crustal melting associated with an AFC process (Nicholson et al. 1991; Sigmarsson et al. 1991; Gunnarsson et al. 1998; Martin and Sigmarsson 2007; Zellmer et al. 2008; Chekol et al. 2011; Kuritani et al. 2011; Bindeman et al. 2012). Elsewhere, such as at Hekla volcano, different magma types have less contrasting isotope ratios with the exception of Th and a few heavy stable isotopes.

Identifying crustal melts and their proportions in mingled or mixed magma is straightforward when the crust has a contrasting isotope composition compared to mantle derived basalts. Such a discrimination is not straightforward for partial melts of young oceanic or oceanic island crusts where classic radiogenic isotope ratios, such as those of $\mathrm{Sr}$ and $\mathrm{Nd}$, remains indistinguishable from the pristine mantle melts. This is because the low ratio of radioactive versus radiogenic isotopes together with long half-life of the radioactive parent isotope lead to slow production of the radiogenic daughter isotope in a crust of young age. Such is the case of the young Icelandic crust. Therefore, isotopes with a short half-life (such as that of ${ }^{230} \mathrm{Th}$ with 
a half-life of only $75 \mathrm{kyrs}$ ) are needed to detect contributions from young mafic crust. Lower Th isotope ratio in a metabasaltic crust that is a few million years old relative to recently erupted basalts is thus an excellent tracer to decipher oceanic crustal contamination (e.g. Nicholson et al. 1991; Sigmarsson et al. 1991). Recently, it has been proposed that the Hekla silicic magma with low Th isotope ratios resulted from fractional crystallisation of basaltic parental magma and "storage in a molten stage over tens of thousands of years" before its eruptions (Geist et al. 2021) rather than being the product of crustal anatexis and rapid transfer to the surface (Sigmarsson et al. 1992).

The Hekla magma suite is frequently chosen for testing the effects of terrestrial magma differentiation on heavy stable isotope composition (e.g. Tuller-Ross et al. 2019). However, a lack of consensus concerning the exact differentiation mechanism producing the Hekla magma suite, namely whether the suite is co-genetic or not, hampers its value for studying magmatic processes. The disagreement appears to lie in the understanding of different tools for identifying the differentiation processes in operation. The most important divergence in view concerns the role of apatite during magma differentiation and the storage time of silicic melts at depth. Can the observed increase in Th/U from basalt to rhyolite (Sigmarsson et al. 1992) simply be explained by extraction of apatite from the melt (Geist et al. 2021)? Or does the higher $\mathrm{Th} / \mathrm{U}$ in silicic Hekla magma reflect an origin from anatectic melting (Sigmarsson et al. 1992)? Lower $\left({ }^{230} \mathrm{Th} /{ }^{232} \mathrm{Th}\right)$ in the silicic magma in the former case could be interpreted as being the result of fractional crystallisation of basalt to produce the entire Hekla magma suite, followed by a long storage time at depth (tens of thousands years). In the second case, the silicic magma could have erupted shortly after anatexis with the rhyolite simply originating from fractional crystallisation of the dacitic crustal melt.

In order to assess if apatite fractionation lowers $\mathrm{Th} / \mathrm{U}$ in the derived melt, selected trace element partition coefficients between minerals and melt were measured in four rock types chosen to represent the Hekla magma series. Moreover, additional field and geochemical data have been integrated to discuss the different hypotheses proposed for the origin of the silicic magma. It is shown that apatite fractionation from Hekla magma has a negligible effect on the $\mathrm{Th} / \mathrm{U}$ in the fractionated melt. Furthermore, new Th isotope ratios in two-coloured tephra layers confirm lower ratios in the more evolved magma. Rapid magma differentiation and eruption is shown to be fully compatible with the lower Th isotope ratios in the silicic magmas compared to the basalt and basaltic andesite magmas. Short timescales of magma evolution concur with the well-known eruption history whereas long-term storage of silicic melt somewhere beneath the volcano which is not involved in the numerous eruptions of the whole magma suite, from basalt to rhyolite, is considered unlikely. Finally, the erupted magma compositions are used to infer the nature of the crustal magma source and the partial melting conditions during the formation of the silicic magma under Hekla.

\section{Hekla magmas and samples}

The Hekla volcanic system (Fig. 1a) is constructed on older crust at the junction between a transform fault and a southward propagating rift into the metabasaltic crust (e.g. Sæmundsson 1979; Meyer et al. 1985, Óskarsson et al. 1982). Its basement is built up of Pleistocene hyaloclastite ridges of basaltic composition and Mt. Hekla is only known to have produced differentiated magma during the Holocene. Prehistoric Plinian eruptions of Hekla (Hekla-5, -4 
and -3 eruptions) produced compositionally zoned tephra layers ranging from rhyolite at the base to andesite and basaltic andesite tephra at the top, whereas basaltic andesite and basalt are respectively erupted from Hekla proper and fissures around the volcano (e.g. Sigvaldason 1974; Larsen and Thorarinsson 1977; Jakobsson 1979; Sigmarsson et al. 1992; Sverrisdóttir 2007). Recent work on the prehistoric tephra stratigraphy has led to an increased understanding of it (Larsen et al. 2019), yielding a better time series of the volcanic and magmatic evolution of Mt. Hekla. After the Hekla-3 eruption (3000 years ago) a series of two-coloured (or bimodal) tephra were erupted (Fig. 1b), followed by more mafic compositions until historical times in Iceland $(\sim 870 \mathrm{CE})$. The first two historical eruptions produced rhyodacite (Hekla-1 eruption; 1104 CE; Thorarinsson 1967) and dacite (1158 CE) magmas. Since then, basaltic andesite to evolved iron-rich andesite (icelandite) have been the dominant eruption products.

\section{The bimodal tephra suite}

The well-known silicic tephra layers from the Plinian Hekla-5, -4 and -3 eruptions (7100, 4250 and 3050 years ago, respectively) characterize the early history of Hekla activity (Fig. 2). Smaller silicic eruptions also produced compositionally zoned tephra layers such as the HÖ eruption, approximately 6100 years ago (Gudmundsdóttir et al. 2011; Jónsson et al. 2020). Recently, Larsen et al. (2019) demonstrated a shift in the eruption mode of Hekla which occurred approximately 3000 years ago, or soon after the large compositionally zoned Hekla-3 Plinian eruption. From 3050 b2k (age before the year $2000 \mathrm{CE}$ ) the volcanic activity changed from infrequent large explosive eruptions to frequent smaller eruptions until the first historical eruption occurred, namely the Plinian 1104 CE, or Hekla-1, eruption. For a 600year period after the Hekla-3 eruption, nine two-coloured tephra layers were formed with a volumetrically smaller light coloured lower part (evolved iron-rich andesite) and a dominant dark upper unit of basaltic andesite composition (Fig. 1b). This was followed by a 500-years period of andesitic production with an increase in eruption of basaltic tephra towards the end of the prehistoric period prior to the Hekla-1 eruption. Eight units were selected from the four largest two-coloured tephra layers, H-X (2260 b2k), H-Y (2680 b2k), H-B (2800 b2k) and H$\mathrm{C}(2840 \mathrm{~b} 2 \mathrm{k})$, from which cm-sized pumice fragments were collected and analysed together with twenty lavas and tephra from Sigmarsson et al. (1992). The sample suite represents the entire age range of products from the Hekla volcanic system.

\section{Tephra for mineral-melt partition analysis}

Four tephra of lapilli size were collected for in-situ measurements of selected trace element partition coefficients, namely basalt scoria from the Lambafit 1913 CE crater row (Moune et al. 2007), basaltic andesite from the $1970 \mathrm{CE}$ craters (Baldridge et al. 1973), the $1158 \mathrm{CE}$ dacitic tephra (Larsen et al. 1999) and a rhyolite from the first phase of the Hekla-3 eruption (Larsen and Thorarinsson 1977). The samples were chosen to represent the range in magma composition of the Hekla volcanic system. They correspond to tephra of different eruption types, from scoria derived from a low-energy fire fountaining basalt fissure eruption to silicic pumice of a Plinian eruption, which produced cubic kilometre of tephra. All the analytical methods and results are given in Supplementary Information 1 and 2, respectively.

\section{Results}


Partition coefficients, or the distribution of an element between two phases in thermodynamic equilibrium, can be measured if equilibrium conditions are met. Textural equilibrium between minerals and glass was examined with a scanning electron microscope (SEM) and assessed based on the sharpness of the crystal faces and signs of resorption in contact with the surrounding glass (see Fig.1 in Supplementary Information 1). Once textural equilibrium had been established, chemical equilibrium was evaluated using existing minerals-melt equilibrium relationships. For olivine-, plagioclase- and pyroxene-melt equilibrium, the criteria discussed in Putirka (2008 and references therein) was employed together with that of Bacon and Hirschmann (1988) for coexisting FeTi-oxides.

Ninety-six olivine crystals, 148 plagioclases and 117 clinopyroxenes were analysed for major elements. No pyroxene was found in the 1970 basaltic andesite, but 30 FeTi-oxides could be analysed. Limited chemical zonation was observed in most macrocrysts apart from the plagioclase in $\mathrm{H} 1970$ which was normally zoned from $\mathrm{An}_{57}$ to $\mathrm{An}_{45}$. The mineral composition is within the published range for the 1913 basalt, the 1970 basaltic andesite and the H3 rhyolite (Baldridge et al. 1972; Moune et al. 2007; Chekol et al. 2011; Portnyagin et al. 2012; Lucic et al. 2016, Weber and Castro 2017; Geist et al. 2021). Olivine in the H1158 dacite was homogeneous with a median composition of $\mathrm{Fo}_{23.6}$ (rim: Fo23-25; core: Fo23-24). In contrast, both normal and reversed zoning was observed in $\mathrm{H} 1158$ plagioclase, ranging in composition from $\mathrm{An}_{56}$ to $\mathrm{An}_{36}$. Similarly, clinopyroxene ranged in composition from Mg\# 40-46 at the rim to Mg\# 39-48 in the cores (median Mg\# of 44 and 40, respectively) and thus mostly displayed reverse zoning.

\section{Major-element concentrations}

Whole-rock major element concentrations were measured in ten new tephra and lavas. The results represent the melt composition because of the aphyric character of the Hekla products. On the total alkali vs silica (TAS) diagram (Fig. 3) the analyses form a complete magma suite when plotted together with those previously published by Sigmarsson et al. (1992), Chekov et al. (2011) and Geist et al (2021). A linear correlation is observed from the more evolved basalt to the rhyolite composition. In order to minimize inter-laboratory differences, only whole-rock analyses from Clermont-Ferrand and Misasa laboratories are shown in Fig. 3, together with the recent results of Geist et al. (2021) and the detailed basalt study of Jakobsson (1979). Several Harker diagrams are displayed in Supplementary Information 3. The most primitive basalts are pillow fragments from the Pleistocene hyaloclastite (Hek-4 and -10; Supplementary Information 2) that forms the basement upon which Hekla volcano is constructed $(\mathrm{MgO} \leq 7.73 \%)$.

The variations in $\mathrm{P}_{2} \mathrm{O}_{5}$ concentrations with magma differentiation are shown against those of $\mathrm{MgO}$ in figure 4 together with whole-rock lava values from the litterature (Jakobsson 1979; Chekol et al. 2011; Geist et al. 2021) and lapilli-sized tephra by Larsen et al. (2019) for comparison. Historical basalt lavas fall on a slightly different curve compared to prehistoric basalt, both of which reach the maximal $\mathrm{P}_{2} \mathrm{O}_{5}$ values of $1.4-1.6 \%$ in the relatively primitive basaltic andesite of the Valagjá chasm (sample Hek-11 and Hek-11b; Table 1 in Supplementary Information 2). From this peak two linear trends of falling $\mathrm{P}_{2} \mathrm{O}_{5}$ vs $\mathrm{MgO}$ are observed. The main trend extends from the Valagjá basaltic andesite to the initial tephra of the 1947 eruption (sample H1947F in Supplementary Information 2 with $\mathrm{MgO}=1.46 \%$ ) and 
olivine-hosted melt inclusions from dacite and rhyolite (Portnyagin et al. 2012; Lucic et al. 2016; not plotted for clarity). A secondary trend is formed by several basaltic andesites that pre-date the $\mathrm{H} 3$ eruption (3000 a) originating from craters on the northern part of the Hekla ridge and lavas close to the Older Valagjá crater.

\section{Trace-element concentrations}

Increasing $\mathrm{SiO}_{2}$ and decreasing $\mathrm{MgO}$ concentrations are often used as differentiation index for magma suites but highly incompatible elements amplify the variability of elemental concentration during magma differentiation. While $\mathrm{SiO}_{2}$ concentrations increase from $45 \%$ to $75 \%$ on an anhydrous basis from basalt to rhyolite (Fig. 3), the Th concentrations increase by a factor of 6 (Fig. 5a). Thorium is therefore used to measure the evolution of the magma composition. Variations of $\mathrm{TiO}_{2}$ with Th concentrations are shown in Fig. 5b. A sharp increase in $\mathrm{TiO}_{2}$ is observed with increasing $\mathrm{Th}$ in the basalts up to a $\mathrm{TiO}_{2}$ concentration around $5 \%$. From there, $\mathrm{TiO}_{2}$ concentrations falls from basaltic andesite to dacite and rhyolite.

Forty-eight trace elements, analysed for 20 samples representing the whole Hekla magma suite, complement the trace element analyses of Sigmarsson et al. (1992) and the study of the most recent Hekla lavas by Chekol et al. (2011) and Geist et al. (2021). The multi-element ICP-MS analyses yield that are results coherent with the ID-MS analyses for U and Th concentrations albeit less precise (see Supplementary Information 2 and 4). Uranium and other large-ion lithophile element concentrations (such as those of $\mathrm{Cs}$ and $\mathrm{Rb}$; see Supplementary Information 4) form an excellent linear correlation with Th, as expressed by squared correlation coefficient, $\mathrm{R}^{2}$, higher than 0.96 . Basalt to basaltic andesite lavas fall on a line passing through the origin for light and middle Rare Earth Elements (LREE and MREE, respectively) versus Th concentration diagrams. Smaller increase in LREE is observed from basaltic andesite to silicic magma while MREE decrease from basaltic andesite to dacite and then rise again in the most evolved rhyolite (Supplementary Information 4). Increasing Th/U with differentiation (Sigmarsson et al. 1992) is confirmed by the new results (Fig. 6). The change in REE occurs at a Th concentration equal to $4 \mathrm{ppm}$ whereas a rise in $\mathrm{Th} / \mathrm{U}$ occurs at Th of 5-6 ppm. Zirconium concentration deviates from the line defined by the basalts at a similar Th concentrations to those of the REE. It varies by a factor of 5 in the silicic magmas while Th differs by less than a factor of 2 (Fig. 6). Evolved andesite from the bimodal tephra frequently deviate from the main evolution trends on concentration plots.

Samarium concentration in basalts correlate linearly with that of Th with a line extending from the origin towards basaltic andesite at approximately $15 \mathrm{ppm}$ of $\mathrm{Sm}$ (Fig. 7). From there a flat trend connects basaltic andesite (via andesite) with dacite/rhyolite until a final rise is observed in the most evolved rhyolite of the zoned $\mathrm{H} 4$ eruption (H4-5). The evolved andesite from the bimodal tephra layers falls well below the general trend. Basalt and basaltic andesite magmas have uniform $\mathrm{Gd} / \mathrm{Yb}$ of 2.45-2.70, falling to approximately 2 in the andesite (Fig. 7). The lowest ratio of 1.7 is measured in HY-A, an evolved andesite, but remain constant at 1.81.9 in silicic magma from Hekla. Silicic magma from Torfajökull, Tindfjallajökull and Snæfellsjökull (Martin and Sigmarsson 2007; Zellmer et al. 2008; Kokfelt et al. 2009; Tomlinson et al. 2010) have Gd/Yb ranging from 1.54 to 2.2, similar to that of Hekla. 
A total of 111 laser-ablation analyses were performed on mineral and glass phases in H1913, H1970, H1158 and H3 tephra and 71 partition coefficients were calculated (Supplementary Information 5 and 6; Fig.8). In plagioclase, $\mathrm{Sr}$ is the only element of those analysed that is considered compatible $\left(D_{\min / \text { melt }}>1\right)$, together with $\mathrm{Eu}\left(\mathrm{D}^{\mathrm{Eu}}=1.21\right)$ in the silicic rocks. The $\mathrm{D}_{\text {plag-melt }}$ for $\mathrm{Sr}$ and Eu increase by up to an order of magnitude from the more primitive H1913-Lambafit basalt $\left(D^{\mathrm{Sr}}=1.53\right.$ and $\left.D^{\mathrm{Eu}}=0.14\right)$ to the $\mathrm{H} 1158$ dacite $\left(\mathrm{D}^{\mathrm{Sr}}=3.73\right.$ and $\mathrm{D}^{\mathrm{Eu}}$ $=1.21$ ). In clinopyroxene, $\mathrm{Sc}, \mathrm{Cr}$, Co and $\mathrm{Ni}$ are compatible together with a few REE in the more evolved $\mathrm{H} 1158$ dacite and $\mathrm{H} 3$ rhyolite, $\mathrm{D}^{\mathrm{Sm}}=1.62-1.75, \mathrm{D}^{\mathrm{Gd}}=1.93-1.96$ and $\mathrm{D}^{\mathrm{Yb}}=$ 1.59-1.70. Yttrium is also compatible in clinopyroxene from $\mathrm{H} 1158$ and $\mathrm{H} 3$ with $\mathrm{D}^{\mathrm{Y}}=1.57$ 1.66. None of the elements measured are compatible in olivine, and the highest $\mathrm{D}$ calculated is that of $\mathrm{Sc}(\sim 0.5)$.

Primary emphasis was put on measuring the partition coefficients for apatite-melt pairs in Hekla and the mean D is found to be consistent from one rock type to another (Supplementary Information 5; Fig. 8a). Rubidium, $\mathrm{Nb}$ and $\mathrm{Ba}$ are incompatible in apatite, as is $\mathrm{Zr}$ to a lesser degree. The highest partition coefficients are observed for the MREE (Nd, Gd, Sm, Pr) then the LREE (La, Ce) and Y with the HREE (Yb and Lu) having the lowest D. Strontium has a somewhat lower $\mathrm{D}$ but $\mathrm{Th}$ and $\mathrm{U}$ are equally compatible in the apatite with $\mathrm{D}^{\text {ap-melt }}$ ranging from approximately 1 in the basaltic andesite $[\mathrm{D}(\mathrm{Th})=0.80 \pm 0.16$ and $\mathrm{D}(\mathrm{U})=0.95 \pm 0.22$ $(2 \sigma)]$ to 2 in the rhyolite $[\mathrm{D}(\mathrm{Th})=1.9 \pm 0.4$ and $\mathrm{D}(\mathrm{U})=1.9 \pm 0.4(2 \sigma)]$. The $\mathrm{D}^{\text {apt-melt }}$ of this study agree with experimental results (Watson and Green 1981; Klemme and Dalpé 2003; Prowatke and Klemme 2006; Fig. 8b). It is noteworthy that there is again a consistent increase in $\mathrm{D}^{\text {apt-melt }}$ from the basaltic andesite through the dacite to the rhyolite by a factor of approximately 3 for each element. Apatite has $\mathrm{D}^{\mathrm{U}}$ and $\mathrm{D}^{\mathrm{Th}}$ approaching a value of 2 and the ratio of $\mathrm{D}^{\text {Th }}$ over $\mathrm{D}^{\mathrm{U}}$ is always within error of 1 (Table 1).

\section{Thorium isotope ratios, $T h / U$ and ${ }^{230} T h-{ }^{238} U$ disequilibria}

The Th/U of 3.2 in Recent Hekla basalts and basaltic andesite contrasts with increasing ratio of 3.4 in the dacite and 3.6-3.7 in the rhyolite. Zircon fractionation and accumulation observed in the zoned H4 eruption caused large variations in Th/U (Sigmarsson et al. 1992), whereas relatively high ratios are measured in two of the bimodal andesites (Fig.6b).

Four pairs of evolved andesite or basaltic andesite from the sequence of bimodal tephra layers yielded significantly lower $\left({ }^{230} \mathrm{Th} /{ }^{232} \mathrm{Th}\right.$ ) and higher $\mathrm{Th} / \mathrm{U}$ in the silicic part (Fig. 9 and Supplementary Information 2). As an example the light-coloured (Fig. 1b) silicic part of the HY tephra layer has $\left({ }^{230} \mathrm{Th} /{ }^{232} \mathrm{Th}\right)$ and $\mathrm{Th} / \mathrm{U}$ of $0.936( \pm 0.008 ; 2 \mathrm{SD})$ and $3.44( \pm 1 \%)$, respectively, compared to $1.030( \pm 0.014 ; 2 \mathrm{SD})$ and 3.25 in the darker part. Two magma types of a contrasting composition are thus erupted in a single eruption. The evolved andesites of the bimodal tephra have relatively low $\left({ }^{230} \mathrm{Th} /{ }^{232} \mathrm{Th}\right)$ for a given Th concentration (Fig. 9). Moreover, these evolved andesites have significantly lower ${ }^{230} \mathrm{Th}$-excess over ${ }^{238} \mathrm{U}$ than dacites or rhyolites from Hekla (Fig. 10). The new results confirm the already observed difference between silicic and more mafic magmas from Hekla (Sigmarsson et al. 1992). 


\section{Discussion}

\section{The Hekla magma suite revisited}

Recently, studies of "non-traditional" stable isotopes of a number of elements have used Hekla volcano as a case study for evaluating the effect of magma differentiation on the systematics of a given isotope. Clearly, understanding of terrestrial fractionation is needed before the physical and chemical processes occurring on a planetary scale can be discussed. While isotopes of several elements either show no isotope fractionation at Hekla (e.g. Zn, Mo and K; Chen et al. 2013; Yang et al. 2015; Tuller-Ross et al. 2019), or non-systematic variations (e.g. Li and Tl isotopes; Schuessler et al. 2009; Prytulak et al. 2017a), other isotope systems (Fe, Si, V, Ti and Zr) display clear evolutionary trends (Schuessler et al. 2009; Savage et al. 2011; Prytulak et al. 2017b; Deng et al. 2018; Inglis et al., 2019). The heavier $\mathrm{Fe}, \mathrm{V}, \mathrm{Ti}$ and $\mathrm{Si}$ isotope ratios with magma differentiation have been suggested to reflect either Rayleigh fractionation, redox variations (with FeTi-oxide fractionating Fe, V and Ti isotopes) or thermogravitational differentiation (e.g. Zambardi et al. 2014 and references therein), whereas the possibility of crustal contamination is rarely explored. Similarly, conflicting interpretations have arisen with respect to $\mathrm{Zr}$ isotope results in Hekla rocks, with either isotopically light zircon being extracted during magmatic differentiation (Inglis et al. 2019) or isotopically heavy $\mathrm{Zr}$ being inherited from crustal anatexis (Ibañez-Mejia and Tissot 2019). The latter proposition is in accordance with the interpretation of B isotopes (RoseKoga and Sigmarsson, 2008). Therefore, the lack of consensus concerning the exact differentiation mechanism operating beneath Hekla hampers accurate interpretation of several heavy stable isotope systematics when applied to a magma suite.

Tight correlations of major- and trace-elements have been used as an argument for magma differentiation by fractional crystallisation alone (e.g. Kokfelt et al. 2009; Geist et al. 2021). However, melt and rhyolite-melt models of fractional crystallisation processes have failed to explain several major element variations, such as those of $\mathrm{Fe}_{2} \mathrm{O}_{3}$ and $\mathrm{K}_{2} \mathrm{O}$ (Chekol et al. 2011) and $\mathrm{Al}_{2} \mathrm{O}_{3}$ and $\mathrm{P}_{2} \mathrm{O}_{5}$, in the Hekla magma suite (Geist et al. 2021). Moreover, the analytical precision of major- and trace-element measurements is not always good enough to distinguish between magma differentiation from a basaltic parent magma by fractional crystallization alone or by assimilation fractional crystallization (AFC) process with dominant magma mixing between silicic crustal melt and more mafic melts (e.g. Sigmarsson et al. 1992). The complication is illustrated by the $\mathrm{TiO}_{2}$ vs Th concentration diagram (Fig. 5b), which could be used to support either interpretation. The divergent view on silicic magma formation at Hekla (e.g. Sigmarsson et al. 1992; Chekol et al. 2011; Portnyagin et al. 2012; Geist et al. 2021) centres around the role of apatite fractionation and its effect on trace element systematics during magma differentiation together with interpretations of low Th isotope ratios in the silicic magma.

\section{Apatite fractionation}

Highest $\mathrm{P}_{2} \mathrm{O}_{5}$ concentrations are observed in the basaltic andesite of the Valagjá lava chasm (Hek-11) and associated volcanic bomb (Hek-11bis), which tephrachronology shows to be older than the $\mathrm{H} 3$ eruption (3050 years ago) but younger than $\mathrm{H} 4$ (4250 years ago). Apatite fractionation would cause a decrease of $\mathrm{P}_{2} \mathrm{O}_{5}$ in the derived melt, which coincides with the transition from evolved basalt to basaltic andesite. However, the straight line of decreasing $\mathrm{P}_{2} \mathrm{O}_{5}$ and $\mathrm{MgO}$ could also represent magma mixing. The decrease in $\mathrm{P}_{2} \mathrm{O}_{5}$ is different before 
and after the $\mathrm{H} 3$ eruption as reflected by different slopes on Fig. 4 which might suggest either more apatite fractionation in the past or different silicic end-members during magma mixing or AFC:-

Fractional crystallisation of apatite has been called upon to explain the REE patterns in several magma suites such as that of Snæfellsjökull and Hekla volcanoes (Kokfelt et al. 2009; Chekol et al. 2011). Apatite fractionation is known to deplete the residual melt in REE, especially the MREE. Experimental studies have shown that $\mathrm{D}^{\mathrm{ap} / \mathrm{melt}}$ is higher for MREE than light or heavy REE (Prowatke and Klemme 2006; Fig. 8). The deflection in REE concentrations when examined against an index of magma differentiation for Hekla occurs at a Th concentration equal to $4 \mathrm{ppm}$ (Fig. 7). It appears to coincide with apatite fractionation, starting at magma composition corresponding to the basaltic andesite of Valagjá with approximately $1.6 \% \mathrm{P}_{2} \mathrm{O}_{5}$ and Th close to $4 \mathrm{ppm}$ (Figs. 4). However, the rise in $\mathrm{Th} / \mathrm{U}$ starts later in the magma evolution at a Th concentration of 5 to $6 \mathrm{ppm}$ (Fig .6b).

\section{Apatite partition coefficients}

The measured $\mathrm{D}^{\text {ap-melt }}$ confirm the correlations with $\mathrm{SiO}_{2}$ concentrations, or the melt polymerization, as experimentally observed (e.g. Prowatke and Klemme, 2006; Fig. 8b). The partition coefficients are thus strongly composition dependent. For example $\mathrm{D}_{\mathrm{Sm}}$ between clinopyroxene and melt increases by a factor of 4 from $0.41( \pm 0.04 ; 2 \sigma)$ in the $1913 \mathrm{CE}$ basalt to $1.75( \pm 0.22 ; 2 \sigma)$ in the $\mathrm{H} 3$ rhyolite and that of apatite-melt reaches values as high as 40 for the MREE.

The new partition coefficients allow better quantification of the differentiation process as illustrated by the Sm vs Th diagram (Fig. 7). The best-fit linear correlation between Sm and Th concentrations in basalts passes through the origin with a slope corresponding to a bulk $\mathrm{D}_{\mathrm{Sm}}$ of 0.002 , readily explained by small proportions of clinopyroxene in the crystallising assemblage. Slightly decreasing Sm concentrations from basaltic andesites ( $\mathrm{Th}=4 \mathrm{ppm})$ to Hek-8 dacite $(\mathrm{Th}=7.75 \mathrm{ppm})$ and an abrupt decrease to evolved andesite HY-A (Th $=6.68$ ppm) would correspond to bulk $D_{\text {Sm }}$ of 1.15 and 1.7, respectively, with an increase in apatite fraction in the crystallising assemblage from 5 to $8 \%$. The final rise in Sm from dacite to rhyolite could then indicate the end of apatite fractionation. Fractional crystallisation of clinopyroxene and significant fraction of apatite could thus, in principle, account for the Sm Th systematics in Hekla products, although it can by no means be used as proof for that process. Indeed, the flat trend around $15 \mathrm{ppm} \mathrm{Sm}$ from basaltic andesite through andesite and dacite towards rhyolite (from 4 to $10.5 \mathrm{ppm}$ Th) is equally well explained by binary mixing and/or AFC with a small mass of crystal fractionation relative to melt assimilant.

Further assessment of the fractional crystallisation mechanism for magma composition varying from basaltic andesite to dacite can be obtained from the measured $\mathrm{D}^{\text {ap-melt }}$ for $\mathrm{Gd}, \mathrm{Yb}$ and Th. Five percent apatite in the fractionating mineral assemblage has been suggested from major-element modelling (Chekol et al. 2011). Apatite is the only mineral, in the present case, that incorporates Th with a $\mathrm{D}^{\text {ap-melt }}$ of 0.8 in the basaltic andesite. From these parameters, 50\% fractional crystallisation of basaltic andesite with $4 \mathrm{ppm}$ Th would produce dacitic magma with $7.8 \mathrm{ppm}$ Th. With $\mathrm{D}^{\text {ap-melt }}$ in the basaltic andesite of 13 for Gd and 4.9 for $\mathrm{Yb}$ (Supplementary Information 5), and assuming an average $\mathrm{D}^{\text {cpx-melt }}$ for basaltic andesite from those measured in the basalt and dacite and further assuming that clinopyroxene makes up half the mass of the fractionating phases, the Gd concentrations would decrease from 16.1 in 
basaltic andesite (with $4 \mathrm{ppm}$ Th) to $8.87 \mathrm{ppm}$, whereas Yb would only slightly decrease from $6.29 \mathrm{ppm}$ to $6.19 \mathrm{ppm}$. This would lead to a decrease in $\mathrm{Gd} / \mathrm{Yb}$ from 2.6 to 1.43 , which is significantly lower than that found in Hekla silicic magma (Fig. 7). In addition, the calculated $\mathrm{Gd}$ and $\mathrm{Yb}$ concentrations in the hypothetical dacite are too low compared to those measured in Hekla dacites, which have values of 14.6 - $15.1 \mathrm{ppm}$ for $\mathrm{Gd}$ and 7.33 - $8.66 \mathrm{ppm}$ for $\mathrm{Yb}$. Lowering the proportions of clinopyroxene fractionation to only $10 \%$, for the sake of argument, yields $\mathrm{Gd}$ and $\mathrm{Yb}$ concentrations (12.4 and $8.51 \mathrm{ppm}$, respectively) closer to the observed values but still results in a $\mathrm{Gd} / \mathrm{Yb}$ of 1.43 , which is significantly lower than the actual value. A simple fractional crystallization model thus underestimates MREE concentrations and their ratios in the derived melt compared to those measured in Hekla dacite.

The strongest argument against major apatite fractionation is the indistinguishable $\mathrm{D}^{\mathrm{U}}$ and $\mathrm{D}^{\mathrm{Th}}$ between apatite and melt, which clearly eliminates the theory that apatite fractionation could explain the higher $\mathrm{Th} / \mathrm{U}$ in the silica rich magma of Hekla. Therefore, fractional crystallisation of parental basalt cannot explain all the trace element systematics of the Hekla magma suite.

\section{Source of silicic Hekla magmas}

Silicic magmas from the rift-zone in Iceland are characterized by low $\delta^{18} \mathrm{O}$ whereas those far from the rift-axis have higher $\delta^{18} \mathrm{O}$ (Martin and Sigmarsson 2007; Schattel et al. 2014 and references therein). Less intense basaltic magmatism away from the rift-zones leads to a lower geothermal gradient and cooler crust that causes incoming basalts to loose heat and differentiate mainly via fractional crystallisation to produce silicic derivatives (e.g. Öræfajökull and Eyjafjallajökull volcanoes; Selbekk and Trønnes 2007; Sigmarsson et al. 2011). In contrast, hotter crust from intense basaltic magmatism is expected at the rift-axis, which is consequently easier to partially melt. High permeability of the intensively fractured crust in rift-zones leads to hydrothermal alteration of the dominant basaltic lavas and intrusive rocks. The oxygen isotope composition of the altered bulk crust depends on several factors such as alteration temperature, secondary mineral fractionations of O-isotopes, degree of hydration and degree of metamorphism together with the composition of the thermal water, which in Iceland ranges from $\delta^{18} \mathrm{O}$ of -20.8 to $+2.3 \%$ (SMOW; Stefánsson et al. 2017). Consequently, hydrothermally altered basalts have large range of $\delta^{18} \mathrm{O}$ or from -11 to $+6 \%$ (Hattori and Muehlenbachs 1982). Mount Hekla, being located on a flank zone with no extensional tectonics, produces dacite and rhyolite with relatively high $\delta^{18} \mathrm{O}$ compared to riftzone rhyolites (e.g. Muehlenbachs et al. 1974; Sigmarsson et al. 1992; Bindeman et al. 2012; Geist et al. 2021). The water content of the crustal source for Hekla silicic rocks can be estimated from the olivine-hosted melt inclusions of Portnyagin et al. (2012) and Lucic et al. (2016). Dacite melts within $\mathrm{Fo}_{25}$ olivine were shown to contain approximately $4 \% \mathrm{H}_{2} \mathrm{O}$. If the dacite were formed by $10-20 \%$ dehydration melting of amphibolite under fluid-absent conditions (Thy et al. 1990; Sigmarsson et al. 1992) then the water content of that amphibolite source would only have to be $0.4-0.8 \%$ since water behaves incompatibly with respect to "water-free" residual minerals after amphibole breakdown. Such a low water content would be expected if the hydrothermal alteration occurred at a relatively low water-rock ratio (Hattori and Muehlenbachs 1982), explaining why the silicic rocks of Hekla do not have very low $\delta^{18} \mathrm{O}$. 
Zircons extracted from a single Hekla tephra layer (most likely that of the $\mathrm{H} 3$ eruption) by Carley et al. (2011) exhibit complex compositional zonation, have an order of magnitude variation in REE concentrations and $\delta^{18} \mathrm{O}$ that varies from 1.8 to $4.8 \%$ (SMOW) suggesting an entrained crystal cargo of diverse origin (Bindeman et al. 2012). These zircons also span a surprising range in Th isotope ratio with $\left({ }^{230} \mathrm{Th} /{ }^{232} \mathrm{Th}\right)$ ranging from 0.18 to 2.22 . None of these zircons have reached radioactive equilibrium between ${ }^{238} \mathrm{U}$ and ${ }^{230} \mathrm{Th}$ and must therefore be younger than $\sim 400 \mathrm{ka}$. The zircon results demonstrate important crustal heterogeneity beneath Hekla and they record crystal ages of several tens to hundreds of thousands of years beneath Hekla volcano, possibly from silicic segregations present within the old metabasaltic crust and defrosted by thermal pulses from the southward propagating rift (Sigurdsson 1977; Gunnarsson et al. 1998). At first glance, this timescale is comparable to that discussed by Chekol et al. (2011) for the production of andesite from a basaltic parent. However, such a long timescale is inconsistent with the eruption history of the silicic Hekla magma. It calls for isolated silicic magma pockets to have remained molten over tens to hundreds of thousands of years, beneath the volcano but to have escaped ascending basalt, basaltic andesite or andesite during the entire volcanic history of Hekla, which appears rather fortuitous. Elsewhere, zircons have been suggested to be recycled between solidification and defrosting (Cooper and Kent, 2014) in mature magma systems, which is an unlikely scenario for Hekla due to its aphyric magma and young age. Therefore, these heterogeneous zircons are most likely xenocrysts and do not convey much information about the formation of the silicic magma. The rarity of crystals in Hekla magmas and the absence of complex zoning in those present (e.g. Sigvaldason 1974; Geist et al. 2021) is best explained by crustal melting and dominant melt mixing at the origin of Hekla evolved magmas (Fig. 9).

\section{Radioactive disequilibrium and time constraints}

Decreasing $\left({ }^{230} \mathrm{Th} /{ }^{232} \mathrm{Th}\right)$ and $\left({ }^{238} \mathrm{U} /{ }^{232} \mathrm{Th}\right)$ with magma differentiation for the entire Hekla magma suite is shown in Fig. 10. If the whole suite were generated by fractional crystallisation alone, a period of 130 thousand years would be needed to decrease the $\left({ }^{230} \mathrm{Th} /{ }^{232} \mathrm{Th}\right)$ from 1.08 (the highest ratio in basalts) to 0.94 (lowest ratio in evolved andesite). The dacite and rhyolite would have to remain for $10^{4}-10^{5}$ years at depth, which is clearly not supported by the volcanic history of Mt. Hekla. Therefore, the lower $\left({ }^{230} \mathrm{Th} /{ }^{232} \mathrm{Th}\right)$ in the silicic magma of Hekla is best explained by metabasaltic crustal anatexis (Sigmarsson et al. 1991).

The tectonic situation of Hekla volcano, namely at the intersection of a transform fault and a propagating rift segment (Saemundsson 1979), suggests a source of relatively fertile metabasaltic crust generated and hydrothermally altered at a rift-axis, and metamorphosed as a consequence of isostasy from the loading of volcanic products and plate spreading (e.g. Óskarsson et al., 1982). To produce ${ }^{230} \mathrm{Th}$ excesses, or $\left({ }^{230} \mathrm{Th} /{ }^{238} \mathrm{U}\right)$ higher than 1 , with partial melting of metabasaltic crust, or amphibolite, a residual mineral phase during melting is needed that is capable of retaining $U$ relative to $T h$. The most likely candidate is a Ti-bearing phase (hemoilmenite-ulvospinel solid solutions or rutile) with higher $\mathrm{D}^{\mathrm{U}}$ than $\mathrm{D}^{\mathrm{Th}}$. Klemme et al. (2006) measured partition coefficients between FeTi-oxides and melt and found that $\mathrm{D}^{\mathrm{U}}$ was less than or equal to 0.01 and that of $\mathrm{D}^{\mathrm{Th}}$ an order of magnitude lower. Such low partition coefficients cannot explain $\left({ }^{230} \mathrm{Th} /{ }^{238} \mathrm{U}\right)$ of $1.10-1.20$ in silicic magma generated by 10 to $20 \%$ dehydration melting of amphibolite. The melting degree would have to be an order of magnitude smaller to yield a reasonable residue with 5-20\% FeTi-oxides. In addition, a melt 
fraction of only $1 \%$ would yield high-silica rhyolite rather than dacite. Dacitic melt with $\left({ }^{230} \mathrm{Th} /{ }^{238} \mathrm{U}\right)$ of 1.10 to 1.20 can be generated by $10-20 \%$ amphibolite melting if the proportions of rutile in the residue are between 0.5 and $2.5 \%$, assuming rutile-melt $\mathrm{D}^{\mathrm{U}}$ of 2 and $\mathrm{D}^{\mathrm{Th}}$ of 0 . Indeed, Klemme et al. (2005) found $\mathrm{D}^{\mathrm{Th}}$ to be less than 0.004 for rutile whereas that of $\mathrm{D}^{\mathrm{U}}$ was frequently higher than 1 and even reached 3.8 in their melting experiments. Residual rutile after $20 \%$ melting of a mafic crust with $\mathrm{Nb} / \mathrm{La}$ of 1.3 yields dacite with $\mathrm{Nb} / \mathrm{La}$ of 0.93 (assuming $0.5 \%$ rutile in the residue and $\mathrm{D}^{\mathrm{Nb}}$ and $\mathrm{D}^{\mathrm{La}}$ between rutile and melt of 20 and 0.003, respectively) as observed at Hekla (range: 0.9-1.1). Thus residual rutile is the most likely cause of the $10-20 \%{ }^{230} \mathrm{Th}$ excess over ${ }^{238} \mathrm{U}$ in the silicic rocks of Hekla, and their formation must occur in the deepest part of the crust due to the pressure dependent stability of rutile (Xiong et al. 2005; Angiboust and Harlov 2017). Melt inclusions (Portnyagin et al. 2012; Lucic et al. 2016) reveal $\mathrm{H}_{2} \mathrm{O}$ contents as high as 5-6 wt \%, which suggest an elevated crystallisation pressure for the olivine to explain the high water solubility in the entrapped silicic melt. Furthermore, high volatile solubility results in low enough viscosity and density to generate the buoyant force for the crustal melt to migrate to higher level where the final phase equilibria of the silica-rich magma took place $(5-6.6 \mathrm{~km}$ according to the melting experiments of Weber and Castro 2017).

The crustal melt produced over the Holocene cannot have had a constant composition as demonstrated by variable $\left({ }^{230} \mathrm{Th} /{ }^{232} \mathrm{Th}\right)$ in the evolved andesite, dacites and rhyolites (Fig. 9). Lower $\mathrm{SiO}_{2}$ and Th concentrations as well as lower $\left({ }^{230} \mathrm{Th} /{ }^{232} \mathrm{Th}\right)$ and $\left({ }^{230} \mathrm{Th} /{ }^{238} \mathrm{U}\right)$, compared to earlier formed dacites, occur in the evolved andesite of the bimodal tephra that were erupted soon after the H3 eruption. Between H3 (3050 BP) and H1 (1104 CE) basaltic andesite became the dominant magma type produced by Hekla (Larsen et al. 2019; Fig. 2). From 3050 BP to approximately $2100 \mathrm{BP}$, ten eruptions emitted both evolved andesite and basaltic andesite forming the bimodal tephra layers, with no evidence for magma mingling between the two magma types (Fig. 1b). The composition of these younger evolved andesites suggests a separate crustal source, with lower $\left({ }^{230} \mathrm{Th} /{ }^{232} \mathrm{Th}\right)$ in the crustal melt. That source would have produced higher melt fractions (to explain lower $\mathrm{SiO}_{2}$ and $\mathrm{Th}$ concentrations as well as lower ${ }^{230} \mathrm{Th}$ excess over ${ }^{238} \mathrm{U}$; Fig. 10). The increased eruption frequency of the basaltic andesite after the $\mathrm{H} 3$ eruption implies a greater flux of hot mafic magma into the magma system and consequently increased latent heat from basalt crystallisation forming the basaltic andesite. Both these factors would facilitate a larger degree of crustal melting if other parameters remained constant. Melting experiments studying the phase equilibria of these evolved andesites are needed to better understand whether the crustal source was at a different level than for the previous magmas.

\section{Field evidence on time constraints}

The elevated $\mathrm{H}_{2} \mathrm{O}$ and $\mathrm{F}$ concentrations in Hekla melts at depth (Moune et al. 2007; Portnyagin et al. 2012) and the nearly aphyric character of the erupted magma does not indicate a gas-filter pressing mechanism to separate silicic melt from crystals. Rather the high volatile solubility suggests a relatively low viscosity of buoyant melt and both rapid and efficient separation from the solid residue after partial crustal melting. The lack of magma mingling in the two-coloured tephra implies separate magma storage for the bimodal magmas and a short contact time between the two magmas before eruptions. The time interval between these "two-magma" eruptions range from only 30 to 200 yrs. (Larsen et al. 2019) showing 
that silicic magma was generated by crustal melting beneath Hekla on a decadal timescale and erupted without accumulation into a large magma body as suggested, for example, before caldera-forming eruptions, such as the Minoan eruption on Santorini (Druitt et al. 2012). Further field studies are needed to establish the length of the quiescent period before the large zoned Plinian eruptions $\mathrm{H} 3$ and $\mathrm{H} 4$, when compositionally stratified magma chambers were emptied. Judging from the repose time preceding the last rhyodacite eruption in $1104 \mathrm{CE}$ (H1 tephra) at least 200-250 years are needed for the accumulation of silicic magma beneath Hekla before a large explosive eruption.

\section{Conclusion}

The principal conclusions of this study are the following:

- The partition coefficients of $U$ and $T h$ between apatite and melt are identical. Therefore, apatite fractionation cannot explain the higher $\mathrm{Th} / \mathrm{U}$ in the silicic magma from Hekla compared to the basalt and basaltic andesite.

- The higher $\mathrm{Th} / \mathrm{U}$ and lower Th isotope ratios in the silicic magma are best explained by partial melting of a metabasaltic crust and rapid magma ascent through the crust.

- The diverse composition of the Hekla evolved andesite and dacite, the bimodal tephra versus those produced during the large Plinian eruption, suggest a heterogeneous crustal source and variable crustal melt fractions.

- The short quiescent time between the prehistoric eruptions and the lack of magma mingling after the $\mathrm{H} 3$ eruption suggest that the time elapsed between crustal melting episodes and eruptions is in the range of only 10-100 years.

- The time needed for establishing of larger magma reservoirs before the zoned Plinian eruptions is only a few hundred years. The lifetime of the magma reservoirs appears to have shortened with time, becoming only a few tens to a hundred years during the historical period.

- Although Hekla appears to produce more mafic magma with time, the magma system has not yet developed a high-level magma chamber, suggesting that partial melting of the lower to middle crust has given rise to the explosive silicic magma.

\section{Acknowledgements}

Late Sveinn Jakobsson and Kristján Jónasson at the Icelandic Institute of Natural History supplied a few lava samples. Claire Fonquernie, Séverine Moune and Baptiste Haddadi assisted with the mineral separation, Eniko Bali helped with the mineralogy, Gudmundur Gudfinnsson was in charge of the EPMA at Univeristy of Iceland, Krzysztof Suchorski and Benbakkar Mhammed made new whole rock trace and major element analyses, respectively. Fran van Wyk de Vries corrected the English, anonymous reviewer, Denis Geist, Georg Zellmer and the editor, Othmar Müntener, made several constructive comments. All these contributions are gratefully acknowledged. Field work was financed by the bilateral "Jules Verne" programme between France and Iceland and the "ClerVolc laboratoire d'excellence" programme of Agent Nationale de Recherche, France, and Rannis, the Icelandic Centre for Research, both of which funded the analytical work. This is ClerVolc contribution \#? 


\section{References}

Angiboust S, Harlov D (2017) Ilmenite breakdown and rutile-titanite stability in metagranitoids; natural observations and experimental results. Am Mineral 102: 1696-1708 DOI: 10.2138/am-2017-6064.

Bacon CR, Hirschmann MM (1988) Mg/Mn partitioning as a test for equilibrium between $\mathrm{Fe}-$ Ti oxides. Am Min 73:57-61

Baldridge SW, McGetchin TR, Frey FA (1973) Magmatic Evolution of Hekla, Iceland. Contr Mineral Petrol 42:245-258.

Bindeman I, Gurenko A, Carley T, Miller C, Martin E, Sigmarsson O (2012) Silicic magma petrogenesis in Iceland by remelting of hydrothermally altered crust based on oxygen isotope diversity and disequilibria between zircon and magma with implications for MORB. Terra Nova 24:227-232.

Carley TL, Miller CF, Wooden JL, Bindeman IN, Barth AP (2011) Zircon from historic eruptions in Iceland: reconstructing storage and evolution of silicic magmas. Miner Petrol 102:135-161.

Chekol TA, Kobayashi K, Yokoyama T, Sakaguchi C, Nakamura E (2011) Timescales of magma differentiation from basalt to andesite beneath Hekla Volcano, Iceland: Constraints from U-series disequilibria in lavas from the last quarter-millennium flows. Geochim Cosmochim Acta 75:256-283.

Chen $\mathrm{H}$ et al. (2013) Zinc isotope fractionation during magmatic differentiation and the isotopic composition of the bulk Earth. Earth Planet Sci Let 369-370:34-42

Condomines M, Gauthier P-J, Sigmarsson O (2003) Timescales of magma chamber processes and dating of young volcanic rocks. Rev Mineral Geochem 52: 125-174.

Cooper KM, Reid MR (2008) Uranium-series crystal ages. Rev Mineral Geochem 69: 479544.

Cooper KM, Kent AJR (2014) Rapid remobilization of magmatic crystals kept in cold storage. Nature 506: 480-483.

Costa F, Shea T, Ubide T (2020) Diffusion chronometry and the timescales of magmatic processes. Nature Reviews Earth \&Environment. https://doi.org/10.1038/s43017-020-0038- X

Deng Z, Chaussidon M, Savage P, Robert F, Pik R, Moynier F (2018) Titanium isotopes as a tracer for the plume or island arc affinity of felsic rocks. PNAS 2018, 116: 1132-1135. 10.1073/pnas.1809164116.

Geist D, Harpp K, Oswald P, Wallace P, Bindeman I, Christensen B (2021) Hekla revisited: fractionation of a magma body at historical timescales. J Petrol 10.1093/petrology/egab001.

Gudmundsdóttir ER, Larsen G, Eiríksson J (2011) Two new Icelandic tephra markers: The Hekla Ö tephra layer, 6060 cal.yr BP, and Hekla DH tephra layer, 6650 cal. yr BP. Land-sea correlation of mid-Holocene tephra markers. The Holocene 21: 629-639. DOI: 10.1177/0959683610391313. 
1 Gunnarsson B, Marsh B Taylor Jr H (1998) Generation of Icelandic rhyolites: silicic lavas from the Torfajökull central volcano. J Volcanol Geotherm Res 83: 1-45.

Hattori K, Muehlenbachs K (1982) Oxygen isotope ratios of the Icelandic crust. J Geophys Res 87:6559-6565.

Hawkesworth CJ, Blake S, Evans P, Hughes R, MacDonald R, Thomas LE, Turner SP, Zellmer G (2000) Time scales of crystal fractionation in magma chambers - Integrating physical, isotopic and geochemical perspectives. J Petrol 41: 991-1006.

Ibañez-Mejia M, Tissot FLH (2019) Extreme Zr stable isotope fractionation during magmatic fractional crystallization. Sci Adv 5:eaax8648.

Inglis EC, Moynier F, Creech J, Deng Z, Day JMD, Teng F-Z, Bizzarro M (2019) Isotopic fractionation of zirconium during magmatic differentiation and the stable isotope composition of the silicate Earth. Geochim Cosmochim Acta 250:311-323.

Jakobsson SP (1979) Petrology of recent basalts of the Eastern Volcanic Zone, Iceland. Acta Natur Island 26:1-103.

Jónasson K (2007) Silicic volcanism in Iceland: composition and distribution within the active volcanic zones. J. Geodynam 43: 101-117.

Jónsson DF, Gudmundsdóttir E R, Larsen G, Óladóttir B, Erlendsson E. Eddudóttir S, Sigmarsson O (2020) The multi-component Hekla Ö tephra, Iceland: A complex widespread mid-Holocene key tephra layer. J Quaternary Sci 1-12. https://doi: 10.1002/jqs.3180

Klemme S, Dalpé C (2003) Trace-element partitioning between apatite and carbonatite melt. Am Mineral 88:639-646.

Klemme S, Prowatke S, Hametner K, Gunther D (2005) Partitioning of trace elements between rutile and silicate melts: Implications for subduction zones. Geochim Cosmochim Acta 69:2361-2371.

Klemme S, Gunther D, Hametner K, Prowatke S, Zack T (2006) The partitioning of trace elements between ilmenite, ulvospinel, armalcolite and silicate melts with implications for the early differentiation of the moon. Chem Geol 234:251-263

Kokfelt TF, Hoernle K, Lundstrom C, Hauff F, van den Bogaard C (2009) Time-scales for magmatic differentiation at the Snaefellsjökull central volcano, western Iceland: Constraints from U-Th-Pa-Ra disequilibria in post-glacial lavas. Earth Planet Sci Let 73:1120-1144.

Kuritani T, Yokoyama T, Kitagawa H, Kobayashi K, Nakamura E (2011) Geochemical evolution of historical lavas from Askja Volcano, Iceland: Implications for mechanisms and timescalesof magmatic differentiation. Geochim Cosmochim Acta 75: 570-587

Larsen G, Thorarinsson S (1977) H4 and other acid Hekla tephra layers. Jökull 27:28-46.

Larsen G, Dugmore A, Newton A (1999) Geochemistry of historical-age silicic tephras in Iceland. The Holocene 9:463-471

Larsen G, Róbertsdóttir BG, Óladóttir BA, Eiríksson J (2019) shift in eruption mode of Hekla volcano, Iceland, 3000 years ago: two-coloured Hekla tephra series, characteristics, dispersal and age. J Quaternary Sci 1-12. https://doi: 10.1002/jqs.3164 
Lucic G, Berg A-S, Stix J (2016) Water-rich and volatile-undersaturated magmas at Hekla volcano, Iceland. Geochem Geophys Geosyst:17. https://doi:10.1002/2016GC006336.

Martin E, Sigmarsson O (2007) Geographical variations of silicic magma origin in Iceland: the case of Torfajökull, Ljósufjöll and Snæfellsjökull volcanoes. Contrib Mineral Petrol 153:593-605.

Meyer PS, Sigurdsson H, Schilling JG (1985) Petrological and geochemical variations along Iceland's Neovolcanic zones. J Geophys Res 90:10043-10072.

Moune S, Sigmarsson O, Thordarson Th, Gauthier P-J (2007) Recent volatile evolution in the magmatic system of Hekla volcano, Iceland. Earth Planet Sci Lett 255:373-389.

Muehlenbachs K, Anderson AT, Sigvaldason GE (1974) Low 180 basalts from Iceland. Geochim Comochim Acta 38:577-588.

Nicholson H, Condomines M, Fitton JD, Fallick AE, Grönvold K, Rogers G (1991) Geochemical and isotopic evidence for crustal assimilation beneath Krafla, Iceland. J Petrol 32: 1005-1020.

Óskarsson N, Sigvaldason GE, Steinthórsson S (1982) A dynamic model of rift zone petrogenesis and regional petrology of Iceland. J Petrol 23: 28-74.

Piccoli PM, Candela PA (2002) Apatite in Igneous Systems. Rev Mineral Geochem 48:255292. https://doi.org/10.2138/rmg.2002.48.6

Portnyagin M, Hoernle K, Storm S, Mironov N, van den Bogaard, C, Botcharnikov R (2012) $\mathrm{H} 2 \mathrm{O}-$ rich melt inclusions in fayalitic olivine from Hekla volcano: Implications for phase relationships in silicic systems and driving forces of explosive volcanism on Iceland. Earth Planet Sci Lett 357/358:337-346.

Prowatke S, Klemme S (2006) Trace element partitioning between apatite and silicate melts. Geochim Cosmochim Acta 70:4513-4527.

Prytulak J, Brett A, Webb M, Plank T, Rehkämper M, Savage PS, Woodhead J (2017a) Thallium elemental behavior and stable isotope fractionation during magmatic processes. Chem Geol 448:71-83.

Prytulak J, Sossi PA, Halliday AN, Plank T, Savage PS, Woodhead JD (2017b) Stable vanadium isotopes as a redox proxy in magmatic systems? Geochem Persp Let 3:75-84.

Putirka KD (2008) Thermometers and Barometers for Volcanic Systems. Rev Mineral Geochem 69:61-120. https://doi:10.2138/rmg.2008.69.3

Reagan MK, Sims KW, Erich J, Thomas RB, Cheng H, Edwards RL, Layne G, Ball L (2003) Time-scales of differentiation from mafic parents to rhyolite in North American continental arcs. J Petrol 44: 1703-1726.

Rose-Koga EF, Sigmarsson O (2008) B-O-Th isotope systematics in Icelandic tephra. Chem Geol 255: 454-462.

Saemundsson K (1979) Outline of the geology of Iceland. Jökull 29: 7-28. 
Savage PS, Georg RB, Williams RB, Burton KW, Halliday AN (2011) Silicon isotope fractionation during magmatic differentiation. Geochim Cosmochim Acta 75:6124-6139.

Schattel, N., Portnyagin, M., Golowin, R., Hoernle K, Bindeman I (2014) Contrasting conditions of rift and off-rift silicic magma origin on Iceland. Geophys Res Lett 41:58135820 .

Schuessler JA, Schoenberg R, Sigmarsson O (2008) Iron and lithium isotopes in volcanic rocks from Hekla, Iceland - Implications for stable isotope fractionation during magma differentiation. Chem Geol 258:78-91.

Sigmarsson O, Hémond C, Condomines M, Fourcade S, Óskarsson N (1991) Origin of silicic magma in Iceland revealed by Thorium isotopes. Geology 19: 621-624.

Sigmarsson O, Condomines M, Fourcade S (1992) A detailed Th, Sr, and O isotope study of Hekla: differentiation processes in an Icelandic volcano. Contrib Mineral Petrol 112:20-34.

Sigmarsson O, Vlastelic I, Andreasen R, Bindeman I, Devidal J-L, Moune S, Keiding JK, Larsen G, Höskuldsson A, Thórdarson T (2011) Remobilization of silicic intrusion by mafic magmas during the 2010 Eyjafjallajökull eruption. Solid Earth 2: 271-281.

Sigurdsson H (1977) Generation of Icelandic rhyolites by melting of plagiogranites in the oceanic layer. Nature 269: $25-28$.

Sigvaldason GE (1974) The petrology of Hekla and origin of silicic rocks in Iceland. Eruption of Hekla 1947-1948. Soc Sci Islandica 5:1-44.

Stefánsson A, Hilton DR, Sveinbjörnsdóttir AE, Torssander P, Heinemeier J, Barnes JD, Ono S, Halldórsson SA, Fiebig J, Arnórsson S (2017) Isotope systematics of Icelandic thermal fluids. J Volcanol Geotherm Res 337, 146-64. DOI: 0.1016/j.jvolgeores.2017.02.006

Stelten ME, Cooper KM, Vazquez JA, Calvert AT, Glessner JJG (2015) Mechanisms and timescales of generating eruptible rhyolitic magmas at Yellowstone caldera from zircon and sanidine geochronology and geochemistry. J Petrol 56: 1607-1642.

Sverrisdóttir G (2007) Hybrid magma generation preceding Plinian silicic eruptions at Hekla, Iceland: evidence from mineralogy and chemistry of two zoned deposits. Geological Magazine 144: 643-659. https://doi.org/10.1017/S0016756807003470

Thorarinsson S (1967) The eruptions of Hekla in historical times. In: Einarsson T, Kjartansson G, Thorarinsson S (Eds). The eruption of Hekla 1947-48. I, 1-177. Soc. Sci. Islandica, Reykjavík.

Thy P, Beard JS, Lofgren GE (1990) Experimental constraints on the origin of Icelandic rhyolites. J. Geology 98: 417-421.

Tomlinson EL, Thórdarson T, Müller W, Thirlwall M, Menzies MA (2010) Microanalysis of tephra by LA-ICP-MS - Strategies, advantages and limitations assessed using the Thorsmörk ignimbrite (Southern Iceland). Chem Geol 279:73-89. https://doi:10.1016/j.chemgeo.2010.09.013.

van Achterbergh E, Ryan CG, Jackson SE, Griffin WL (2001) Data reduction software for LA-ICP-MS. In Sylvester PJ (Ed) Laser Ablation - ICP-Mass Spectrometry in the Earth 
Sciences: Principles and Applications (Vol. 29, pp. 239-243). Ottawa: Mineralogical Association of Canada Short Course Series.

Watson E B, Green TH (1981) Apatite/liquid partition coefficients for the rare earth elements and strontium. Earth Planet Sci Lett 56:405-421.

Weber G, Castro JM (2017) Phase petrology reveals shallow magma storage prior to large explosive silicic eruptions at Hekla volcano, Iceland. Earth Planet Sci Lett 466:168-180.

Xiong XL, Adam J, Green TH (2005) Rutile stability and rutile/melt HFSE partitioning during partial melting of hydrous basalt: Implications for TTG genesis. Chem Geol 218: 339359.

Zellmer GF, Rubin KH, Grönvold K, Jurado-Chichay Z (2008) On the recent bimodal magmatic processes and their rates in the Torfajökull-Veidivötn area, Iceland. Earth Planet Sci Lett 269:387-397.

Yang J et al. (2015) Absence of molybdenum isotope fractionation during magmatic differentiation at Hekla volcano, Iceland. Geochim Cosmochim Acta 162:126-136.

\section{Table legend.}

Table 1. Mean partition coefficients between minerals and melt for Th and U.

\section{Figure legends.}

Fig. 1. Left panel shows a digital elevation map of Hekla volcano and the Valagjá chasm. In the right panel the peculiar sharp boundary between evolved andesite and basaltic andesite is shown for the HY bimodal tephra layer.

Fig. 2. Simplified stratigraphic column for tephra layers from Hekla volcano. Note that basalt units are not shown. Historical dates are given as CE (Common Era) and prehistoric dates as before $2000 \mathrm{CE}$ (b2k). Different colours are shown in the on-line version with yellow as rhyolite, orange as dacite and blue for andesite-basaltic andesite tephra.

Fig. 3. The sum of sodium and potassium oxides plotted against silica oxide concentrations (TAS diagram) for Hekla lavas and tephra. Results from Jakobsson (1979), Sigmarsson et al. (1992), Chekol et al. (2011) and Geist et al. (2021) are plotted together with results of this study. All results have been recalculated on an anhydrous basis.

Fig. 4. Concentrations of $\mathrm{P}_{2} \mathrm{O}_{5}$ in historical basalts are higher than in prehistoric basalts for a given $\mathrm{MgO}$. In contrast, $\mathrm{P}_{2} \mathrm{O}_{5}$ decreases faster in older basaltic andesite from the northern part of the Hekla ridge and craters further north along the same strike (Fig. 1) relative to basaltic andesite and andesite younger than the H3 eruption (ca. 3000 a). Two double-headed arrows indicate either apatite fractionation or magma mixing of basaltic andesite with differentiated magma components, with the older one (between Valagjá and Older Valagjá) being of less evolved composition. Results from Jakobsson (1979), Sigmarsson et al. (1992), Chekol et al. 
(2011) and Larsen et al. (2019) are plotted together with those of this study. See text for further discussion.

Fig. 5 a) Thorium vs $\mathrm{SiO}_{2}$ concentrations in Hekla volcanics. The over five-fold rise in $\mathrm{Th}$ corresponds to only a 1.6 times increase in $\mathrm{SiO}_{2}$ concentrations demonstrating that fine details of magma differentiation are better represented by Th variations than by variations in silica. Only Th measured by ID-MS are plotted together with results from Sigmarsson et al. (1992; filled circles) and those of Chekol et al. (2011; empty circles). b) Titanium oxide vs Th concentrations in Hekla volcanics. Onset of FeTi-oxide fractionation in the basalts is marked by the spike in $\mathrm{TiO}_{2}$ concentrations. The decreasing $\mathrm{TiO}_{2}$ with differentiation (increasing $\mathrm{Th}$ ) can be explained by either progressive fractional crystallisation or by magma mixing of different components. Such a mixing line is drawn from the basaltic andesite through andesite towards the dacite.

Fig. 6. a) Zirconium versus Th concentrations. The observed differences between the new results and those of Sigmarsson et al. (1992) reflects the different analytical methods (isotope dilution mass spectrometry, ICP-MS multi-element analysis and XRF on pressed pellets) used in three separate laboratories. Open headed arrows depict fractional crystallisation from basalt to basaltic andesite and from dacite to rhyolite. Binary magma mixing between basaltic andesite and dacite is indicated by the double-headed arrow. Zircon fractionation and accumulation controls the zirconium concentration in products from the $\mathrm{H} 4$ eruption. Also notable is the peculiarity of the evolved andesite from the bimodal tephra layers (HY-A and HX-A). b) Only U and Th results obtained by isotope dilution mass spectrometry are plotted. The Th/U in basalt and basaltic andesite is uniform at 3.2 up to Th 5-6 ppm, from where the ratio increases to $\sim 3.5$. Redistribution of zircon in the $\mathrm{H} 4$ zoned eruption causes $\mathrm{Th} / \mathrm{U}$ to vary between 3.04 and 3.73 .

Fig.7. Rare Earth Element variations examined with increasing magma differentiation in the Hekla magma suite. Analytical errors on the REE concentrations are shown as 3\%. Range of $\mathrm{Gd} / \mathrm{Yb}$ in Icelandic silicic magmas is shown as well. See text for further discussion.

Fig. 8. a) Mean partition coefficients between apatite and melt for intermediate to silicic magma from Hekla. Note the consistent increase in $\mathrm{D}$ from basaltic andesite through dacite to rhyolite. b) Increasing $\mathrm{D}^{\text {ap-melt }}$ with sillica content of the melt. Filled symbols are averages from this study; associated error is in most cases smaller than the size of symbols (see Supplementary Information 5). The $\mathrm{D}^{\text {ap-melt }}$ of $\mathrm{U}$ and $\mathrm{Th}$ are within analytical error and thus overlap each other. Open symbols are experimental apatite/melt partition coefficient from published studies (Watson and Green 1981; Klemme and Dalpé 2003; Prowatke and Klemme 2006; Hammouda et al. 2010) and the calculated exponential best fits are shown as dashed lines for comparison with the new results.

Fig. 9. Thorium isotopes in Recent Hekla magmas plotted against Th concentration and $1 /\left({ }^{232} \mathrm{Th}\right)$ (in grams per disintegration per minute $\left.(\mathrm{dpm})\right)$. Identical $\left({ }^{230} \mathrm{Th} /{ }^{232} \mathrm{Th}\right)$ in basalt and the most primitive basaltic andesite reflects fractional crystallisation (FC). Decreasing $\left({ }^{230} \mathrm{Th} /{ }^{232} \mathrm{Th}\right)$ from basaltic andesite through andesite towards dacite strongly suggests magma mixing with limited crystal-melt separation causing the observed scatter. Fractional crystallisation of dacite produces rhyolite. Evolved andesite from the bimodal tephra sequence are explained by crustal melt of different composition than for the other dacites. See text for further discussion. 
1 Fig. 10. Equiline diagram schematically displaying the mantle source and the metabasaltic 2 crust in U-Th radioactive equilibrium $\left(\left({ }^{230} \mathrm{Th}\right)=\left({ }^{238} \mathrm{U}\right)\right)$ together with the approximate fields 3 for rift-zone basalts Kokfelt et al. (2006 and references therein) and partial metabasalt melts.

4 Ageing and metamorphism of basalts, produced by mantle melting and erupted in the rift-

5 zone, together with isostasy and crustal spreading form amphibolite crust that upon

6 dehydration melting produces the Hekla silicic magmas (Sigmarsson et al. 1991). The spread

7 of results for silicic magma on the diagram suggest a heterogeneous crustal source. Excess

$8 \quad{ }^{230} \mathrm{Th}$ over ${ }^{238} \mathrm{U}$ results from dehydration crustal melting and subsequent zircon fractionation

9 as observed for the rhyolites. The maximum time needed for ${ }^{230} \mathrm{Th}$ decay alone is also

10 indicated. See text for further discussion.

\section{Supplementary Information}

1- Methods and analytical technics

2- Analytical results (Major and trace element concentrations, $U$ and $T h$ concentrations by isotope dilution and $\left({ }^{230} \mathrm{Th} /{ }^{232} \mathrm{Th}\right)$ measurement results)

3- Harker diagrams

4- Trace element plots

5- Measured partition coefficients

6- In-situ trace element results 